\author{
LUIZA RZYMOWSKA \\ ORCID: 0000-0002-2747-5108 \\ Uniwersytet Wrocławski \\ Wydział Filologiczny, Instytut Filologii Polskiej
}

\title{
Kunszt mówcy i kunszt aktora w grecko-rzymskiej tradycji retorycznej
}

\begin{abstract}
Abstrakt
Autorka w niewielkim szkicu ujmuje szeroką, godną osobnej monografii, problematykę piątej części sztuki retorycznej, czyli pronuncjacji, actio, jako obszaru, w którym ujawniają się podobieństwa i różnice między sztuką retoryczną a sztuką aktorską. Skrótowemu uporządkowaniu tych zagadnień poświęca część pierwszą tekstu, w części drugiej zaś przeprowadza analizę i interpretację fragmentów dwóch źródeł antycznych, które mogą służyć do opisu rozdzielenia rzemiosła mówców i rzemiosła aktorów w dziejach retoryki grecko-rzymskiej. Są to księga III Retoryki Arystotelesa oraz księga I traktatu O mówcy Marka Tulliusza Cycerona.
\end{abstract}

Słowa kluczowe: język, komunikacja, sztuka retoryczna, sztuka aktorska, Arystoteles, Cyceron, mowa, mówca, aktor, actio, pronuncjacja, deklamacja, głos, gestykulacja, ruch ciała, Retoryka, O mówcy.

Dla rozdzielenia zakresów sztuki retorycznej i sztuki aktorskiej właściwie wystarczy tylko stwierdzenie faktu, że w retoryce mówca jest twórcą tekstu, aktor zaś wykonuje tekst cudzy. Oczywistość tego stwierdzenia jest jednak pozorna - gaśnie natychmiast, gdy pojawia się obserwacja konkretnych przypadków lub samodoświadczenie oratorskie i/lub teatralne. Poruszając ten temat na poznańskiej konferencji Dydaktyka retoryki, Jerzy Radziwiłowicz, jeden z najwybitniejszych aktorów polskiej sceny, rozdzielił obie sztuki, po czym uczynił charakterystyczne zastrzeżenie:

Aktor zatem nie wypowiada się we własnym imieniu, jak retor, ale w imieniu granej przez siebie postaci (choć i w przypadku retora można mieć pewne podejrzenia, że przemawiając, kiedy da się porwać własnemu głosowi i pięknej wymowie - przy założeniu, że nimi dysponuje - mówi nie tylko w imieniu siebie-autora tekstu, ale też w imieniu siebie-znakomitego wykonawcy, czyli postaci, w jakiej występuje przed słuchaczami). (Radziwiłowicz 2011: 156)

Takich zastrzeżeń i dookreśleń z pewnością można by zgromadzić więcej, prawdopodobnie $z$ tej przyczyny, że proces perswazji, zwany również „procesem retorycznym” (Douglass 2008: 87), jest zjawiskiem niesłychanie złożonym, o charakterze 
socjopsychologicznym. Perswazyjność bowiem zawsze ujawnia się, zdaniem Rodneya B. Douglassa, w trzech współistniejących i współzależnych aspektach: po pierwsze, „narzucając określone formy związku społeczno-sytuacyjnego”; po drugie, „sugerując jakieś sformułowanie (lub obraz) ja-mówiącego”; po trzecie, „wprowadzając określoną postawę wobec świata zewnętrznego, jakiś kształt tego, co było, jest lub ma być" (Douglass 2008: 90). Badacz wyprowadził te wnioski z Arystotelesowskiego rozpoznania, że w perswazji odnajdujemy czynnik społeczny, osobisty oraz intelektualny - wszystkie trzy naraz.

\section{Wyodrębnianie actio w retoryce. Podobieństwa i różnice między sztuką retoryczną a sztuką aktorską}

Prawdą jest również, iż zagadnienia podobieństw i różnic w rzemiośle retora i rzemiośle aktora nie sposób analizować bez odpowiedniego tła: bez zrozumienia, czym jest dla mówcy ostatni etap metodycznego postępowania, czyli stworzenie wygłoszenia przygotowanego tekstu. Wówczas zdania - wymyślone, ułożone i przyobleczone w określony styl, być może zanotowane lub dosłownie zapamiętane - zmieniają się we frazy: akcentowane, intonowane i modulowane odpowiednim głosem, podkreślane mimiką, uwypuklane gestem, oddawane ruchem całego ciała, a nawet scenografią miejsca wystąpienia. W sztuce retoryki przejście od tekstu napisanego do wygłoszonego jest jak przejście w twórczości malarskiej, fotograficznej czy filmowej od perspektywy linearnej do perspektywy sferycznej: efekt głębi, który wówczas powstaje, działa we wszystkich kierunkach. Na przykład analiza rytmizacji tekstu mówcy bez analizy rytmizacji jego ruchów (przy możliwości obserwowania mówcy lub przy pracy z zapisem audiowizualnym przemówienia) byłaby nieuzasadnioną redukcją materiału. „Słowo jest gestem - pisał Maurice Merleau-Ponty - a jego znaczenie światem" (Merleau-Ponty 1999: 95).

Jeśli założymy, że komunikowanie retoryczne to swoisty język mówcy, a komunikowanie sceniczne to język aktora, nie dokonamy opisu tych kodów bez wiedzy o relacji pomiędzy językowymi a niejęzykowymi środkami komunikacji w teorii retorycznej. O tych ostatnich pisała Barbara Sobczak, formułując ważną tezę o zakresie actio - piątej części wśród partes artis rhetoricae:

Punktem wyjścia tych rozważań chciałabym uczynić tezę, że potencjał perswazyjny, który tkwi w nadawcy, a który ma się ujawnić na etapie actio, wynika z takich czynników, jak wiarygodność, kompetencja, podobieństwo do odbiorcy, sympatia, jaką budzi, i charyzma, a wszystkie one w mniejszym lub większym stopniu budowane są z tego, co pozasłowne. O czym wiedzieli już starożytni, a co w ostatnich dziesięcioleciach jest przedmiotem wielu badań, zwłaszcza psychologów, organizacja komunikacji nie przebiega wyłącznie na poziomie werbalnym. Człowiek przemawia całym swoim ciałem i z punktu widzenia retoryki pronuncjacja może być skuteczna tylko dzięki współistnieniu działań werbalnych, niewerbalnych i parajęzykowych. (Sobczak 2009: 58) 
Wyszczególnione tutaj działania: werbalne, niewerbalne i parajęzykowe to właściwie nie pojedyncze działania, lecz grupy działań, które jako całość zbliżają do siebie dwie sztuki: retoryczną i aktorską. Mieczysław Kotlarczyk nazywał tę całość „wszelkimi zespołami środków wyrazu w sztuce żywego słowa”, a jako przykłady podawał:

- deklamację;

- recytacje;

- mówienie artystyczne (Kotlarczyk 1965: 216).

Zbliża owe sztuki jeszcze jedno: do obu ściśle przylega sztuka pamięci, czyli mnemonika (memoria). Bez zapamiętywania tekstu nie ma warsztatu aktora. Sztuka wygłaszania mowy, czyli pronuncjacja (actio), nie pojedynczo, lecz właśnie wraz ze sztuką zapamiętywania oddziela się od inventio, dispositio i elocutio, ponieważ obie operują gotowym już projektem tekstu mowy. Czwarty i piąty z kolei etap postępowania mówcy są ze sobą w specjalny sposób złączone, gdyż tworzą jeden tor czynności mówcy: od momentu podjęcia przez niego decyzji o treści i formie mowy do momentu samospełnienia w zdarzeniu retorycznym, w akcie wystąpienia przed audytorium. Ten fakt uwzględnia Jerzy Ziomek w Retoryce opisowej, podkreślając pragmatyczną jedność ostatnich etapów w refleksji na temat nieproporcjonalnego rozkładu teorii w schemacie perypatetyckim retoryki, gdzie ilościowo dominuje wykład o elokucji:

Mniej mieliśmy — poniekąd wbrew oczekiwaniom — do powiedzenia na temat dyspozycji, a jeszcze mniej powiemy o dwu ostatnich częściach, a mianowicie o pamięci (memoria) i wykonaniu (pronuntiatio, który to termin łaciński oznacza zarówno „obwieszczenie”, jak „wypowiedzenie”, „odczyt”, „wyrok” i - w sensie fonetycznym - „wymowę”). Przyczyna jest dość oczywista: w praktyce umiejętność zapamiętywania tekstu mowy oraz umiejętność jej wygłoszenia, a więc najdosłowniej operowania głosem, była i jest poniekąd darem natury, a poniekąd umiejętnością pochodzącą z nauki i doświadczenia. (Ziomek 2000: 245)

I właśnie w tym miejscu, orzekłszy o wrodzonym charakterze umiejętności doskonalonych na dwóch ostatnich etapach przygotowania mowy, Ziomek wprowadza zagadnienie podobieństwa retoryki do sztuki aktorskiej:

Te części sztuki wymowy przypominają sztukę aktorską, a nawet są jej wręcz pokrewne. I to podobieństwo dobrze uświadamia skalę oraz rodzaj trudności w zapisie reguł sztukami tymi rządzących: reguł jest niewiele i są na ogół proste, ich przekazywanie wszakże odbywa się zazwyczaj przez pokaz i naśladownictwo. (Ziomek 2000: 245)

Słusznie została tutaj podkreślona rola ekspozycji społecznej w opanowywaniu jednej i drugiej sztuki. Jednakże rzekomej prostocie reguł zapamiętywania i wygłaszania tekstu zgodnie zaprzeczyliby specjaliści, eksperci w dwóch głównych zakresach actio: we właściwym użyciu głosu oraz ruchu ciała przez mówców. Niewątpliwie prosta jest reguła mówiąca o tym, że bez prawidłowego oddychania — oddychania przeponowego - nie mogą zaistnieć w pełnym wymiarze trzy podstawowe jakości głosu mówcy czy aktora: słyszalność, wyraźność i (artystyczna) wyrazistość. Reguły 
kształcenia doskonałej artykulacji komplikuje jednak samo ich zróżnicowanie świetnej dykcji można się uczyć na różne sposoby, zależnie od przyjętej metody, od szkoły, od tradycji, a podawane prawidła są bardzo złożone, gdyż obejmują ćwiczenia rozmaitych aspektów użycia instrumentu głosowego. Mimo wielu cech wspólnych polskie podręczniki kultury żywego słowa różnią się między sobą.

Należy też podkreślić, że już w starożytności odróżniano kształcenie głosu spontaniczne, instynktowne od kształcenia profesjonalnego. Gdy Krassus w Cycerońskim traktacie $O$ mówcy komentuje rolę ćwiczeń retorycznych, zauważa (nawiązując do znanej sentencji - Scribere scribendo, dicendi dicere disces):

A przecież większość przy tym ćwiczy tylko głos (i to jeszcze nieumiejętnie) oraz swą tężyznę, jak też pobudza język do szybkiego ruchu i rozkoszuje się mnogością słów. Mylą się w tym, co usłyszeli, że ludzie zazwyczaj nabywają zdolność mówienia mówiąc. Prawdziwe jest również powiedzenie, że dzięki błędnemu mówieniu ludzie bardzo łatwo osiągają to, że mówią błędnie. (Cyceron 2010: I 149-150)

Wtrącenie (po słowach sed plerique in hoc vocem modo): neque eam scienter zdradza, że Arpinata jest zorientowany w charakterze ćwiczeń głosowych.

Problematyka podobieństwa - czy nawet pokrewieństwa - sztuki oratorskiej i sztuki aktorskiej zawiera o wiele więcej takich zagadnień mogących stanowić przedmiot dyskusji. Bez wątpienia zatem zasługuje na osobną monografię. Także w obszarze różnic między sztukami retoryczną i aktorską można wytypować godne zbadania zagadnienia. Odrębność kunsztu mówców i kunsztu aktorów nie zarysowuje się wyłącznie w sferze związku wykonawcy tekstu z dziełem własnym lub cudzym. Dodatkowo wskazać należy tutaj trzy kwestie - przechodzę więc do ich omówienia.

\section{Kwestia ogólnych celów sztuki}

Należy przede wszystkim rozdzielić ogólne cele obu sztuk. W retoryce barwność i siła actio, odpowiednie użycie głosu mają ułatwić operowanie funkcją estetyczną i wpływać na uczucia, mają dopełnić całego wygłoszenia i ukonstytuować względem słuchaczy postać przemawiającej osoby. Nie są to jednak środki właściwe dla sztuki wymowy, gdyby bowiem takimi były, to ich maksymalne czy mistrzowskie użycie czyniłoby mówcę jeszcze lepszym, a już starożytni teoretycy zauważyli, że tak nie jest. U mówców, u których jest jakaś przesada czy jakieś szczególne wyrafinowanie w użyciu środków aktorskich, związanych z wyraźnością i wyrazistością głosu oraz ze sposobem operowania mimiką i gestykulacją, nie obserwujemy daru przekonywania - ich teatralna maniera wręcz przeszkadza słuchaczom. Wybornie ujął to Kwintylian w Kształceniu mówcy:

Tak samo nie należy brać od aktorów każdego ich gestu czy każdego ruchu w postawie ciała. Chociaż bowiem mówca powinien dać z siebie i jedno, i drugie, to jednak musi się on trzymać w tym wszystkim jak najdalej od formy scenicznej i nie przesadzać ani w mimice, ani w ruchach rąk, ani 
w sposobie stawiania kroków. Bo jeżeli w ogóle obowiązuje mówcę w tych rzeczach jakaś sztuka, to przede wszystkim ta, żeby się nie wydawać sztucznym! (Kwintylian 2002: I, 11, 3)

Retoryka jest logocentryczna, promuje przede wszystkim elokucję, sztukę wysłowienia. Jako dzieło sztuki retorycznej bardziej zachwycają płynność mówienia, blask wypowiadanych słów niż nadzwyczajne, aktorskie środki wyrazu podczas oracji. To wszystko, co idzie za słowem, co tworzy ramę, tło, dopełnienie jego bogactwa, mimo niedostatków wygłoszenia, mimo pewnych usterek będzie zawsze inaczej pojmowane w kontekście zdarzenia retorycznego, które nie ma takiej dramaturgii jak wydarzenie sceniczne, gdzie aktor odgrywa rolę w określonym kostiumie, na scenie.

Czy na tej scenie również jest ważne unikanie przesady? Kotlarczyk, autor kanonicznych już Podstaw sztuki żywego słowa, posługiwał się pojęciem „, artystycznych języków interpretacyjnych", dla których widział w swoich czasach następujący cel: "dążenie i zbliżanie się do prawdy i prostoty" (Kotlarczyk 1965: 216). Autor pisał: „[...] wszelkie języki interpretacyjne powinny strzec się fałszu i przesady, czyli sztuczności, która jest zaprzeczeniem prawdy i prostoty" (Kotlarczyk 1965: 216 n.)

Ideę prawdy i prostoty twórca Teatru Rapsodycznego odnajdywał w świecie literatury i muzyki: Norwidowskiej teorii białego kwiatu, „czyli teorii ściszenia, stonowania, odpoetyzowania i dyskrecji środków artystycznego wyrazu” (Kotlarczyk 1965: 217), w postulatach Juliusza Słowackiego oraz w Chopinowskiej — łagodnej i poetycznej - technice koncertowania. Szukał jej również w programach estetycznych szkół teatralnych: w krakowskiej szkole Koźmiana, uczącej aktorów powściągliwości, oraz Reducie Juliusza Osterwy, inspirowanej poglądami Cypriana Kamila Norwida, która wypracowała specyficzny polski styl gry scenicznej. Z określenia takich celów wypływa zagadnienie naturalności środków wyrazu, jak się okazuje, istotne także dla sztuki aktorskiej.

\section{Kwestia naturalności}

W drugiej połowie XX wieku, gdy powstawał podręcznik Kotlarczyka, szczególnie mocno oddzielano w sztukach widowiskowych to, co nowoczesne, od tego, co przestarzałe. Naturalność, do której artyści nieraz dążyli na drogach rozwoju rozmaitych sztuk, stała się w tym okresie synonimem nowoczesności. Dlatego Kotlarczyk pisze, że „W zgodzie z nowoczesnością pozostaje każdy postulat, żeby język interpretacyjny posługiwał się jedynie naturalnymi i prostymi środkami wyrazu" (Kotlarczyk 1965: 217). Prawdy i prostoty, będących celem tej sztuki, nie traktował autor jak jakichś abstrakcji, gdy pisał:

Przejawiają się one najkonkretniej poprzez nasz głos, poprzez warstwę brzmieniową sztuki żywego
słowa, poprzez dykcję artysty i najrozmaitsze środki wyrazu oraz ich zespoły. Zależą od takiego,
a nie innego tempa, rytmu, dynamiki, intonacji, barwy, frazowania czy operowania pauzą arty-
styczną. Zależą od obserwacji i przestrzegania praw i prawideł rządzących naturą tych środków.
Osiągnięcie ich zależy od wielu współczynników techniki, artyzmu i kultury samego artysty, od 
stopnia rozwoju jego świadomości, od stopnia sprawności funkcji jego kory mózgowej, po prostu od jego mózgu. (Kotlarczyk 1965: 217)

Z kolei w historii retoryki grecko-rzymskiej zawsze - nie tylko w wybranych nurtach - obowiązywała naturalność actio, naturalna ekspresja głosu i ciała, co wiązało się oczywiście z pojmowaniem retoryki jako zbioru zasad o charakterze naturalnym ${ }^{1}$. Jeśli zatem w obu zakresach pronuncjacji coś szlifowano, czyniono to po mocniczo - na przykład tak w Grecji, jak i w Rzymie poszukiwano nauczycieli tego, co dziś nazywamy emisją głosu. Wybitni mówcy w wielu sprawach radzili się aktorów: mamy przekaz, że ze szkoleń u aktorów korzystali Demostenes i Cyceron, aby reperować swój instrument głosowy czy korygować postawę ciała podczas oracji.

W sztuce retoryki w naszym kręgu kulturowym paleta środków służących wygłoszeniu mowy może jedynie przy p o m i nać warsztat pracy aktora — środki, którymi dysponuje dany aktor w szczególności i którymi rozporządza sztuka aktorska w ogólności, mimo zbliżenia obu sztuk w kwestii pozytywnego wartościowania naturalności wystąpień oratorskich i występów artystycznych.

To, co naturalnie dane osobie, jest bezcenne. Cyceron pisze, że „jest bardzo wiele umiejętności, których jeśli mówca nie otrzymał w darze od natury, nauczyciel niewiele mu pomoże w ich zdobyciu" (Cyceron 2010, I 126). Zarazem to, co wrodzone, może być rozwijane. Wiadomo, że aktorstwo to nie jedynie emisja głosu, lecz także praca nad jego ekspresją; nie tylko odpowiednia postawa na scenie, lecz także praca nad ekspresją ruchu - mimiki, gestyki i całego ciała. Czy ten rodzaj świadomego kształtowania ekspresji zarówno głosu, jak i ruchu stanowi jakąś wartość dla mówców, przygotowujących się do wystąpień publicznych? Odpowiedź może być tylko twierdząca. Będziemy nawet w stanie wskazać na upodobnienie drogi samorozwoju mówcy do drogi samodoskonalenia aktora — pod warunkiem, że odniesiemy się do właściwej szkoły aktorskiej. Powinniśmy rozpoznać taką metodę, która pozwala osobie ludzkiej odkryć w sobie i rozwinąć dynamikę mowy i cielesności - dynamikę naturalną. Gdybyśmy chcieli poszukać tego pierwiastka naturalnego pośród słynnych szkół aktorstwa, szkół o tradycji żywej i dzisiaj, musielibyśmy w tych rozważaniach wyeliminować zwłaszcza szkołę biomechaniki Wsiewołoda Meyerholda, traktującą aktora jak lalkę mechaniczną, a wybrać szkołę Konstantego Stanisławskiego - z jej akcentowaniem wyobraźni, uczuć, przeżycia osobistego, pamięci, z uruchamianiem zmysłów. Ta szkoła bez wątpienia byłaby punktem stycznym pomiędzy ekspresją głosu i ciała zalecaną w retoryce a ekspresją wykorzystywaną w aktorstwie.

\section{Kwestia dążenia do jedności}

Należy też zaznaczyć istotną różnicę $\mathrm{w}$ dążeniu do różnych doskonałości w obrębie tych sztuk: dla aktora ważne jest osiągnięcie jedności psychofizycznej z odgrywaną przez niego postacią, mówca zaś ma ustanowić jedność pomiędzy własną myślą

${ }^{1}$ Szczegółowo pisałam o tym w rozdziale Retoryka jako naturalna umiejętność osoby w książce U źródeł pojmowania retoryki (Rzymowska 2013: 56-77). 
a własnym słowem i to ma się przełożyć na jego głos i ciało. W księdze III dialogu O mówcy Krassus jest bliski objaśnienia tej różnicy, gdy opisuje rozmówcom gest oratora, który za pomocą modulacji głosu przekazuje dowolne uczucia:

Wszystkim tym wzruszeniom powinien towarzyszyć odpowiedni gest, nie taki, jak ten, którym aktor wyraża na scenie słowa, lecz wskazujący na jakąś ogólną myśl bez jej wyraźnego pokazywania, a jedynie ją sugerując. (Cyceron 2010: III, 220)

Oczekiwane jest powstanie wrażenia jedności środków przekonywania, ponieważ publiczność zawsze jest zaniepokojona, gdy jakiś element wypada z całości podejrzewa wtedy jakąś złą intencję czy manipulację — i zawsze odbiera przekaz jako niewiarygodny, gdy mówca nie jest spójny, kongruentny i gdy nie przejawia się w nim poczucie koherencji. Dążenie do jedności środków przekonywania sprzyja wzbudzeniu zaufania. Według Arystotelesa budzi zaufanie u słuchaczy ten, kto wykaże się posiadaniem wszystkich trzech cech: rozsądku, szlachetności i życzliwości (Arystoteles 2014: II 1378 a). Spójność wizerunku mówcy jako i rozsądnego, i pod jakimś względem szlachetnego, i życzliwego słuchaczom gwarantuje, że jego przekaz jawi się audytorium jako wiarygodny. Trudno byłoby mówcy zagrać, że posiada owe trzy cechy naraz - wymagałoby to umiejętności aktorskich, gdyż nieudolna próba zagrania nieuchronnie demaskuje grę, która w tym przypadku udaremniałaby zamiar.

Ale z kolei mówca, który nie korzysta w ogóle z tego warsztatu, jakim dysponuje aktor, mógłby pozostać tylko logografem, mógłby w samotności kreować przemówienia, a ich nie wygłaszać. Dlatego tak ważne jest oparcie wygłoszenia na pewnych elementach sztuki aktorskiej i aktor może w tym mówcy doradzać. Rozdzielność ich sztuk jest jednak bezsporna i kompetencje są tutaj zupełnie inaczej rozłożone. Natomiast aktor, który zdobyłby pewne umiejętności mówcy, musiałby zostać mówcą i występowałby jako konkretna osoba, spersonalizowana w akcie mówienia.

\section{Dwa antyczne źródła do opisu rozdzielenia sztuki oratorskiej i sztuki aktorskiej w dziejach retoryki}

Rozdzielenie obu sztuk w pismach teoretyków retoryki dokonało się bardzo wcześnie: już u początków kształtowania się $\dot{\eta} \rho \eta \tau o \rho \iota k \dot{~} \tau \dot{\varepsilon} \chi v \eta$, czyli kodyfikacji naturalnych skłonności osoby ludzkiej do przekonywania w antycznej Grecji.

Źródłem greckim, wybranym tutaj do ilustracji zagadnienia, jest III księga Retoryki Arystotelesa. Choć geneza tego dzieła budzi wiele kontrowersji, przyjmuje się dziś na ogół, że jego ostateczna redakcja nastąpiła po 334 roku p.n.e. i że jeśli nawet księga III była pierwotnie samodzielną rozprawą zatytułowaną $O$ stylu, to została wówczas włączona w całość traktatu Stagiryty. W dziejach retoryki zwraca się uwagę na udokumentowaną w Retoryce „świadomość teoretyczną, ogromną wiedzę i rzadki zmysł obserwacyjny filozofa" (Podbielski 2014: 42), jak też na imponujący sposób podporządkowania materiału celom retoryki, zadaniom mówcy i gatun- 
kom wymowy. Paradoksem jest fakt, że „mimo tak wielkiego bogactwa myśli, tak wszechstronnego i zwartego systemu, jaki przedstawia, Retoryka Arystotelesa nie odegrała większej roli w rozwoju antycznej teorii wymowy" (Podbielski 2014: 43) — sprawił to zapewne jej filozoficzny charakter. Nie dotyczy to jednak księgi III - ta wzbudziła duże zainteresowanie.

Jako źródło rzymskie wybrałam I księgę obszernego traktatu O mówcy (De oratore), oddanego do rąk czytelników przez Cycerona pod koniec 55 roku p.n.e., a napisanego na wzór dialogów Platona. Lodovico Dolce podkreślił, że „dzieło to jest zaprawdę najbardziej uczone i najwytworniejsze, jak też najtrudniejsze ze wszystkiego, co napisał Marek Tulliusz" (Awianowicz 2010: 31). Dialog ten znacznie wykracza poza tematykę Retoryki, łączy bowiem teorię wymowy z praktyką oratorską. Fragmenty o sztuce retorycznej i sztuce aktorskiej przewijają się przez cały tekst obfitość takich refleksji znajdziemy zwłaszcza w księdze III, lecz powinny być one przedmiotem analizy w osobnej monografii; tutaj starczy miejsca jedynie na ukazanie, w jaki sposób Arpinata definiuje tę problematykę na początku swojego dzieła.

Kryterium wyboru tych dwóch źródeł - traktatów diametralnie różniących się formą - jest zatem ważkość ich treści. Gdyby zaś powstawała książka na temat poruszony w niniejszym artykule, znalazłby się do niej szerszy, choć nie obfity, materiał źródłowy. Zwłaszcza w retoryce rzymskiej mamy zachowane teksty, zawierające istotną refleksję naukową nad actio: przede wszystkim podręcznik Kornificjusza Rhetorica ad Herennium, który powstał w latach około 86-82 p.n.e., oraz wspomniane tu wcześniej Kształcenie mówcy (Institutio oratoria) Marka Fabiusza Kwintyliana, dzieło ogłoszone przez niego pod sam koniec życia (zmarł około 95 roku). Bardzo ważnym utworem w omawianym kontekście jest też inny dialog Cycerona: Brutus, czyli o sławnych mówcach (Brutus, sive de claris oratoribus), stworzony w 46 roku przed Chrystusem i zawierający - podobnie jak De oratore - bezcenne opisy autentycznych mówców, także niekiedy z uwzględnieniem ich umiejętności wygłaszania.

\section{Księga III Retoryki Arystotelesa}

Interesujące jest, że w greckiej tradycji retorycznej z ogromną niechęcią podchodzono do sztuki aktorskiej, mimo że w jakiejś mierze z niej korzystano. W sferze wygłoszenia nie było bowiem żadnego podręcznika, żadnej kompletnej teorii actio. Arystoteles narzeka, że w jego czasach nie istnieje teoria deklamacji, którą kojarzył z ekspresją głosu, zalecając mówcom zmiany siły, tonacji i barwy głosu. Kiedy jednak skarży się na ten brak, podsumowuje bardzo ostro sztukę aktorską, pisząc, że w zasadzie to błazenada. Deprecjonowano więc aktorów. Było godnością i dumą mówcy nie przypominać aktora.

Prześledzę, jak Stagiryta wprowadza tę problematykę do księgi III Retoryki. Następuje to na samym początku tej księgi, gdy autor określa przedmiot jej wykładu. Autor przechodzi od zagadnień treści do tematyki środków wyrazu artystycznego: 
Nie wystarczy przecież wiedzieć, co należy mówić, ale trzeba też umieć to w należyty sposób wyrazić, ponieważ od tej właśnie umiejętności w dużym stopniu zależy wrażenie, jakie wywołuje mowa. (Arystoteles 2014: III 1403 b)

Zwraca przy tym uwagę, że podział wywodu w Retoryce jest zgodny z naturalnym porządkiem rzeczy. Rozpatrywane są bowiem kolejno:

1. siła przekonywania tkwiąca w samych faktach;

2. wyrażanie faktów za pomocą środków językowych;

3. sprawy związane z wygłoszeniem mowy, „które w ogromnym stopniu decydują o powodzeniu mówcy, a dotąd nie zostały przez nikogo opracowane" (Arystoteles 2014: III 1403 b).

Arystoteles podkreśla, że późne zainteresowanie tymi ostatnimi dotyczy również przedstawień tragedii oraz recytacji epickich. „Wygłoszenie mowy” to tutaj

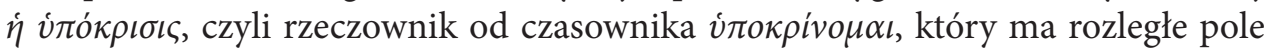
znaczeniowe, oznacza zarówno 'dawać odpowiedź', jak i 'wyjaśniać, wykładać'; zarówno 'mówić dialog, grać rolę na scenie', jak i 'wygłaszać mowy, deklamować' (Słownik grecko-polski 1965: 451) — stąd w polskich przekładach przyjął się termin „sztuka deklamacji”. Dalsze znaczenia zaś pokazują i czynność naśladowania, przedstawiania w sztuce, i czynność udawania, odgrywania roli poza sztuką. Szczegółowo analizuje użycie tego leksemu w Retoryce Ana Kotarcic w wydanej w tym roku książce Aristotle on Language and Style. The Concept of Lexis (Kotarcic 2021: 139-143).

Dla Stagiryty powiązanie sztuki deklamacji z retoryką jest pewną oczywistością, choć zarazem w przedstawieniu jej jako oczywistości kryje się zabieg pomniejszenia jej wartości. Pisze, że wchodzi ona w zakres teorii retorycznej identycznie jak w zakres poetyki, gdzie była przedmiotem badań Glaukona z Teos. Definiuje ją następująco:

Polega ona na umiejętnym wykorzystaniu głosu do wyrażenia poszczególnych uczuć. Trzeba więc wiedzieć, kiedy np. mówić podniesionym głosem, kiedy ściszonym, a kiedy normalnym; poza tym — jakiej kiedy użyć tonacji; kiedy wysokiej, kiedy niskiej i kiedy pośredniej, a także, jaki dostosować rytm do poszczególnego typu wypowiedzi. Mówca musi mieć bowiem na uwadze trzy rzeczy: siłę głosu, wysokość tonacji i rytm. (Arystoteles 2014: III 1403 b)

Sztuka deklamacji opiera się zatem całkowicie na retorycznej zasadzie stosowno-

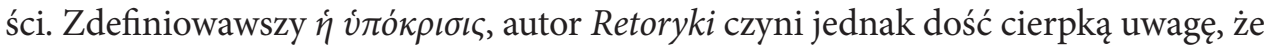
ci, którzy ją opanowali, są nagradzani w konkursach dramatycznych, „gdzie więcej znaczą dziś aktorzy niż poeci, a podobnie dzieje się również podczas debat politycznych na skutek niedoskonałości zasad ustrojowych" (Arystoteles 2014: III 1403 b). Henryk Podbielski podziwia tę Arystotelesową umiejętność dostrzeżenia historycznej prawidłowości w rozwoju sztuki dramatycznej: „po okresie wielkich poetów dramatycznych nastaje epoka wielkich aktorów" (Arystoteles 2014: 172, przyp. 9), czyli epoka dekadencji, triumfu masowego odbiorcy, tymczasem autor Poetyki twierdził, że tragedia oddziałuje nawet bez wystawiania jej na scenie z pomocą aktorów (Arystoteles 2014: 172, przyp. 9). 
Stagiryta zastanawia się następnie nad luką w teorii retorycznej, łącząc hypókrisis ze stylistyką, również niespiesznie się rozwijającą (istotnie badania z tego zakresu zapoczątkowali dopiero sofiści):

Sztuka deklamacji nie została dotąd opracowana, ponieważ do niedawna niewielki był również postęp w badaniach nad językowymi środkami wyrazu. Słusznie zresztą brana jest za błazenadę. Ponieważ jednak wszelkie badania z zakresu retoryki dotyczą opinii ( $\delta o ́ \xi \breve{\alpha})$, trzeba sztuką tą zająć się z należną gorliwością, nie dlatego, że zasługuje na to jej przedmiot, ale ponieważ wymaga tego konieczność. (Arystoteles 2014: III 1403 b-1404 a)

Po tym postulacie następuje swoiste wyjaśnienie:

Jedyną bowiem słuszną rzeczą, o którą powinien zabiegać mówca, jest to, by jego mowa ani nie smuciła, ani nie bawiła słuchaczy. Słuszność wymaga przecież, aby mówcy walczyli ze sobą wyłącznie za pomocą faktów, gdyż wszystko, co nie dotyczy ich udowodnienia, jest zbędnym dodatkiem. Ale, jak powiedzieliśmy, odgrywa ono ogromną rolę ze względu na zepsucie słuchaczy. (Arystoteles 2014: III 1404 a)

Kolejny fragment Retoryki jest świadectwem prymatu treści w systemie retorycznym, pojmowania formy wypowiedzi perswazyjnej jako ważnej tylko z uwagi na słuchacza, lecz nigdy - z uwagi na przedmiot mowy:

We wszelkim jednak nauczaniu, przynajmniej w jakiejś niewielkiej mierze, troska o formę językową jest konieczna. Istnieje przecież różnica, czy coś się wyjaśni w taki czy inny sposób, chociaż nie tak wielka, jak się przypuszcza. Wszystko to jest pozorem i zmierza do pozyskania słuchacza. Dlatego nikt w ten sposób nie naucza geometrii. (Arystoteles 2014: III 1404 a)

Sentencję, która się w tym fragmencie pojawia, warto przytoczyć w języku ory-

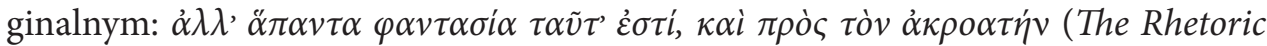
of Aristotle 1877: 8). Rzeczownik, który Podbielski oddaje jako 'pozór', to $\varphi \alpha v \tau \alpha \sigma i \alpha$, fantasia, czyli dosłownie 'wyobraźnia', jak też to, co się w niej zjawia, ukazuje - 'wyobrażenie,' 'wrażenie,' 'wygląd'. Arystoteles wykłada teorię wyobraźni i wyobrażeń w traktacie $O$ duszy. Wyobrażenie zaś cechuje się w filozofii Stagiryty pewną wtórnością: jest ono jakby echem postrzeżenia - echem, śladem, lecz nie jego wierną kopią. Wyobraźnia jest bowiem, obok pamięci biernej i czynnej, władzą funkcjonalnie zależną od działania zmysłów (Swieżawski 2000: 145).

Hypókrisis ostatecznie okazuje się ważna dla retoryki ze względu na oczekiwane efekty w interakcji ze słuchaczami, stąd prognoza:

Kiedy sztuka deklamacji zostanie wykształcona, mówcy będą osiągać te same efekty, co teraz aktorzy. Dotychczas jednak niewielu podjęło próbę opracowania jej zasad i to w skromnym zakresie, np. Trazymach w swych Środkach wzruszania. (Arystoteles 2014: III 1404 a)

Tutaj pojawia się bardzo ciekawe rozróżnienie: trudno opracować teorię środków, jakimi posługują się aktorzy, łatwo zaś - teorię środków językowych:

Kunszt aktorski jest sprawą naturalnego talentu i wymyka się teoretycznemu opracowaniu, natomiast takiemu opracowaniu łatwo poddają się językowe środki wyrazu. Dlatego zdobywają nagrody również ci mówcy, którzy potrafią się nimi posługiwać, podobnie jak je zdobywają mówcy 
obdarzeni talentem aktorskim; pisane mowy wywołują bowiem większe wrażenie swym stylem niż zawartością myślową. (Arystoteles 2014: III 1404 a)

Arystoteles ujął w tym miejscu tekstu kwestię agonów retorycznych: stający do zawodów mówcy zdobywają nagrody ze względu na poklask, ze względu na wrażenie wywarte na słuchaczach. To mogą osiągnąć i ci, którzy wyróżniają się stylem, i ci, którzy wyróżniają się talentem aktorskim. Impulsu dla rozwoju sztuki rapsodycznej i sztuki aktorskiej upatruje jednak autor Retoryki w sztuce poetyckiej:

Pierwszy impuls w tym kierunku dali, rzecz naturalna, poeci, gdyż słowa są naśladowczym przedstawieniem rzeczy, a poza tym posługiwali się głosem, który ze wszystkich wytworów ludzkich organów najbardziej nadaje się do naśladowania rzeczywistości. (Arystoteles 2014: III 1404 a)

W zacytowanych fragmentach filozof bardzo konsekwentnie dokonuje pomniejszenia wartości sztuki deklamacji, przy równoczesnym uznaniu jej znaczenia i przedstawianiu go jako oczywistości. Publiczny charakter akcji retorycznej zmusza mówcę do świadomego używania głosu, lecz Rodney B. Douglass, badając Arystotelesowską koncepcję komunikacji retorycznej, podkreśla, że Stagiryta jest daleki od przeceniania elementów kontroli jej przebiegu. O ile bowiem zainteresowania współczesnych badaczy retoryki koncentrują się na tym,

jak zapanować [control] nad sposobem posługiwania się przez ludzi komunikowaniem retorycznym, jak przewidywać efekty wypowiedzi retorycznej, jak budować wypowiedzi retoryczne według z góry wyznaczonych wzorców efektywności, logiki, etyki lub po prostu tego, co powinno być (Douglass 2008: 92),

o tyle w Retoryce odnajdujemy całkowicie odmienną koncepcję:

Zmierza ona do swobodnego rozumienia procesów retorycznego komunikowania, usiłuje je ujrzeć takimi, jakimi są one rzeczywiście, do uchwycenia tego, co określa ich naturę - i z tych rozważań wyprowadzić opis właściwej człowiekowi umiejętności radzenia sobie z retorycznym doświadczeniem. (Douglass 2008: 92)

Dodałabym tutaj jeszcze rozróżnienie, że gdy u schyłku lat siedemdziesiątych XX wieku — w czasach, w których pisze Douglass — badacze skupili się „na tym, co zapewnia sukces lub panowanie, i na sposobach uczynienia czegoś przekonującym" (Douglass 2008: 92), nie oznaczało to powrotu do Arystotelesowskiego modelu retoryki. Filozof bowiem stworzył jej teoretyczne podstawy zgodnie z własną definicją tej sztuki jako „umiejętności metodycznego odkrywania tego, co w odniesieniu do każdego przedmiotu może być przekonywające" (Retoryka, I 1355 b). Tę definicję odnowionej retoryki wykuł, przypomnijmy, w polemice ze swymi poprzednikami. Odkrywanie w faktach potencji perswazyjnej to inny rodzaj wysiłku niż ten, który sondował Douglass w nurtach współczesnej sobie retoryki.

Skoro zatem komunikację retoryczną ustanawianą przez Arystotelesa można opisać za Douglassem jako „proces funkcjonalny, humanistycznie interakcyjny, proces uwarunkowany sytuacyjnie, dynamiczny, perswazyjny, socjopsychologiczny i dorad- 
czy” (Douglass 2008: 91), to hypókrisis ma w nim dopiero prognozowane miejsce jako część formy wypowiedzi analogiczna do elocutio.

Znamienne jest, że w części III Retoryki Stagiryta, zwracając uwagę na rolę umiejętności aktorskich w wygłoszeniu wybitnych przemówień, splata zagadnienia stylu $\mathrm{z}$ aspektem wygłoszenia:

[...] doskonałe przemówienia mówców okazują się prostackie w rękach czytelników, ponieważ swym stylem dostosowane są do publicznych wystąpień na obradach. Dlatego też odpowiednie dla wygłaszania elementy stylu nie spełniają swego zadania i wydają się naiwne, jeśli pozbawi się je aktorskiego wykonania. (Arystoteles 2014: 1413 b)

Użycie umiejętności aktorskich przez mówcę może również, co dość osobliwe, stanowić ekwiwalent starannego, bogatego w szczegóły stylu:

Tam, gdzie potrzebne są umiejętności aktorskie, niewielką rolę odgrywa staranność stylistyczna; mówca musi mieć natomiast dobry głos, a przede wszystkim donośny. (Arystoteles 2014: 1414 a)

\section{Księga I O mówcy Marka Tulliusza Cycerona}

Zagadnienie wygłaszania mowy z porównaniem do sztuki aktorskiej pojawia się już na pierwszych stronach księgi pierwszej traktatu $O$ mówcy. Cyceron nazywa tę ars przymiotnikiem levis, co znaczy w tym kontekście: 'płocha, błaha, niepoważna'. Po refleksji, że „wymowa jest czymś większym, niż się ludziom wydaje, i składa się na nią wiele nauk i zamiłowań" (Cyceron 2010: I 16), i po wymienieniu wielorakich czynności mówcy z zakresu inventio, dispositio oraz elocutio autor stawia pytania:

Czy bowiem trzeba, bym dalej mówił o samym wygłaszaniu mowy, przy którym należy troszczyć się o stosowny ruch ciała, gesty, wyraz twarzy, o panowanie nad głosem i jego modulacją? Jak wielkie samo poprzez się ma to znaczenie, pokazuje mało poważna sztuka aktorska i scena, na której, choć wszyscy się trudzą, by panować nad twarzą, głosem i ruchem, któż nie wie, jak niewielu jest i było takich, na których możemy patrzeć spokojnie? (Cyceron 2010: I 18)

Następnie przechodzi do namysłu nad pamięcią: „Cóż mam rzec o skarbcu wszystkiego, pamięci?” (Cyceron 2010: I 18). Tutaj zatem sztuka pamięci ułożona została za pronuncjacją — zdarza się to jeszcze w innym miejscu w dialogu O mówcy, że klasyczna kolejność powinności mówcy zostaje zmieniona (Cyceron 2010: I 157). Być może ta wymienność miejsc świadczy właśnie o tym, że actio i memoria stanowią integralną całość. Ciekawe jest również w zacytowanym fragmencie wzmocnienie znaczenia sposobu wygłoszenia mowy poprzez porównanie do pracy aktorów nad swoim warsztatem, która w niewielu przypadkach daje efekt satysfakcjonujący widzów.

Kwestia pronuncjacji pojawia się ponownie w księdze I traktatu jako ostatni element uzupełniający obraz mówcy:

Przeto, jeśli się chce wyczerpująco i trafnie zdefiniować zdolność mówcy, ten będzie według mnie mówcą godnym tego jakże poważnego tytułu, kto na każdy temat, jaki przyjdzie mu przedstawiać w mowie, będzie mówił mądrze i składnie oraz kunsztownie i wykazując przy tym dobrą pamięć, jak również z pełną godności mimiką i gestykulacją. (Cyceron 2010: I 64) 
To, co polski tłumacz, Bartosz Awianowicz, oddaje dwuskładnikowo, jako mimikę i gestykulację, w oryginalnym tekście jest jednym wyrazem: cum quadam actionis etiam dignitate. Całe działanie pronuncjacyjne mówcy ma być pełne godności.

W innym miejscu księgi I czytamy znów o kolejności postępowania mówcy o pięciu powinnościach. Czwarta każe mu tekst zapamiętać, piąta zaś - „wygłosić z godnością i wdziękiem” (Cyceron 2020: I 142), czyli cum dignitate ac venustate, co jest ciekawym połączeniem, gdyż łaciński rzeczownik venustas oznacza i 'wdzięk, powab', i 'czar, urok, urzeczenie'. Podobnie gdy w tej samej księdze Antoniusz definiuje mówcę, uzupełnia jego wizerunek stwierdzeniem:

[...] chcę, by ponadto odznaczał się on odpowiednim głosem, właściwym zachowaniem podczas wygłaszania mowy i jakimś naturalnym wdziękiem. (Cyceron 2010: I 213)

W innym miejscu Krassus podkreśla, że „wielki wpływ na zdolność wymowy wywiera wrodzony talent" (naturam atque ingenium - rzeczownikami natura oraz

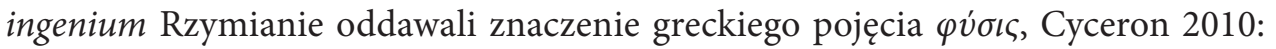
I 133). Tą tezą bohater dialogu Cycerona otwiera dyskusję na temat jednej z triad retorycznych. Tutaj tworzą ją: 1) talent, 2) nauka teorii, 3) ćwiczenie. Wymieniwszy najpierw rozmaite zdolności intelektualne mówcy, stwierdza:

byłoby bowiem wspaniale, jeśliby te zdolności nauka teorii mogła rozpalić i poruszyć; ale poprzez naukę nie można ich zaszczepić i ofiarować; wszystkie one są bowiem darami natury - cóż mam mówić o tym, co bez wątpienia rozwija się wraz z samym człowiekiem, jak: sprawność języka, tembr głosu, płuca, tężyzna fizyczna, określony wyraz i wygląd całego oblicza i ciała? I bynajmniej nie zamierzam przez to powiedzieć, iż nauka teorii nie może pewnych talentów udoskonalić - jestem bowiem świadom tego, że dzięki nauczaniu to, co jest dobre, można uczynić jeszcze lepszym, a to, co nienajlepsze, w jakiś sposób jednak wyostrzyć i poprawić - lecz niektórzy są tak wielkimi jąkałami albo mają tak chrapliwy głos, albo ich mimika i ruchy są tak ociężałe i niezdarne, że nawet jeśliby byli obdarzeni wrodzonym talentem i znajomością teorii, to jednak nie można by ich zaliczyć do grona mówców. Z drugiej zaś strony niektórzy są tak bardzo do tego przystosowani, tak szczodrze obdarowani przez naturę, że, jak się wydaje, nie zrodzili się, lecz zostali stworzeni przez jakiegoś boga. (Cyceron 2010: I 114-115)

W tym fragmencie zostały wyrażone te poglądy na naturalność działania retorycznego, które omówiłam pokrótce w pierwszej części swojego szkicu. W charakterystyczny sposób podkreślił Cyceron udział samej natury w tych elementach actio, które stanowią część wspólną dwóch zbiorów umiejętności - umiejętności mówców i aktorów. Znakomicie zostały tutaj podkreślone tak zwane warunki naturalne osoby jako podstawa jej rzemiosła oratorskiego.

Bardzo ciekawego rozróżnienia dokonuje Cyceron w księdze I mimochodem: koncentrując się na fakcie wywoływania sądów wartościujących u audytorium przez mówcę, zestawia jego wystąpienie z przedstawieniem na scenie, wywołującym określone reakcje publiczności. Dzieli się wówczas takim spostrzeżeniem:

Tak też o przedstawieniach teatralnych, w których szuka się nie niezbędnego pożytku, lecz swobodnej rozrywki duchowej, jakże skrupulatny i niemal wybredny jest nasz sąd! Nie ma bowiem żadnych sporów ani polemik, które zmuszałyby ludzi, by, jak na forum niedobrych mówców, znosili również w teatrze złych aktorów. Mówca musi przeto szczególnie dołożyć starań o to, żeby 
zadowolić nie tylko tych, którym jest niezbędny, lecz również, by wydawać się godnym podziwu również tym, którzy mogą swobodnie wypowiadać swój sąd. (Cyceron 2010, I 118-119)

Zdarzenie retoryczne, spotkanie mówcy ze słuchaczami jest zatem nacechowane poszukiwaniem „niezbędnego pożytku”, a zdarzenie teatralne - poszukiwaniem „swobodnej rozrywki duchowej”. Słowa Cycerona o powinności mówcy odnoszą się do dwóch rodzajów retorycznych: osądzającego (sądowego) i deliberatywnego (doradczego), gdyż wszędzie tam, gdzie mowa ma skutki prawne czy polityczne, mówca jest niezbędny ludziom, których reprezentuje, lub ludziom, którzy po prostu na niego liczą. W świetle tego fragmentu dialogu orator musi pamiętać o regule harmonii rodzajów retorycznych (Korolko 1990: 48) - wymienione wyżej dwa rodzaje tworzą jedność $\mathrm{z}$ rodzajem oceniającym (demonstratywnym), powiązanym z funkcją estetyczną wypowiedzi, spełnianą przez perswazję, gdy mowa odwołuje się do uczuć słuchaczy. Nie ma ucieczki od dbałości o poklask odbiorców, o uznanie publiczne. Analizując podobieństwo sytuacji komunikacyjnej wystąpienia publicznego mówcy i wystąpienia aktora na scenie, widzimy zatem, że częścią wspólną jest funkcja estetyczna dwóch artystycznych wypowiedzi: oratorskiej i aktorskiej. Mowa mówcy musi jednak spełnić także pozostałe funkcje perswazyjne: informująco-pouczającą oraz nakłaniającą.

Jest też warte odnotowania, że Cyceron niejednolicie traktuje gestykulację. Z jednej strony nie waha się ukazać gestyki na niższym miejscu w hierarchii umiejętności mówcy — gestyki, która jest wszak jedną z podstawowych umiejętności aktora. Otóż Antoniusz, inny bohater dialogu, mówi:

Ilekroć bowiem przemawiamy, tylekroć nas się osądza. Kto raz popełni błąd w gestykulacji, nie uważa się natychmiast, że nie zna gestów. Kogo natomiast przyłapie się na jakiejś pomyłce w mowie, przylgnie do niego jeśli nie na wieczność, to z pewnością na długo opinia człowieka mało bystrego. (Cyceron 2010: I 125)

Z drugiej zaś strony Cyceron, ustami Antoniusza, stawia wysokie wymagania mówcy operującemu gestem i tym samym splata sztukę oratorską ze sztuką aktorską, a odcina ją od innych sztuk:

Do zgłębienia innych sztuk wystarczy bowiem jedynie bycie podobnym do człowieka oraz zdolność ogarnięcia umysłem i zachowania w pamięci tego, czego nauczają, lub, jeśli przypadkiem trafi się ktoś mniej pojętny, co mu wbijają do głowy. Nie jest wymagana płynność języka, umiejętność szybkiego wypowiadania słów, wreszcie to, czego nie możemy w sobie zmienić: rysy i wyraz twarzy, głos. Od mówcy zaś trzeba wymagać wnikliwości dialektyków, myśli filozofów, wysłowienia niemalże poetów, pamięci prawników, głosu tragików, gestów prawie najwybitniejszych aktorów. Dlatego też w rodzaju ludzkim nie można znaleźć niczego, co pojawiałoby się rzadziej niż doskonały mówca. (Cyceron 2010: I 127-128)

Wśród najwybitniejszych aktorów rzymskich częstokroć wymieniany jest w traktacie Kwintus Roscjusz, który przyjaźnił się z Arpinatą. Sulla włączył go za jego mistrzowską grę do stanu ekwickiego, a Cyceron poświęcił mu mowę Pro Q. Roscio Comoedo. I oto ów aktor staje się wzorem dla mówców, idealnym mistrzem wystąpień przed publicznością: 
Żeby więc przy pochwale mówcy wziąć sobie za wzór owego aktora, czyż nie widzicie, że nie robi on niczego, co nie jest doskonałe, niczego, czego by nie przedstawił z największym wdziękiem, tak, jak przystoi, i tak, by wszystkich wzruszał oraz bawił? (Cyceron 2010: I 130)

Gdy Krassus wychwala jednego z rozmówców — Sulpicjusza — podkreślając, że „nie słyszał nikogo, kogo cechowałby bardziej właściwy ruch ciała, postawa i sylwetka, ani nikogo obdarzonego pełniejszym i przyjemniejszym głosem" (Cyceron 2010: I 132), jednocześnie przestrzega innych mówców przed przesadą w użyciu tych scenicznych środków. Powołuje się przy tym na Roscjusza, dla którego „najważniejsza w sztuce jest stosowność" (Cyceron 2010: I 132).

I właśnie aktorzy - zdaniem Cycerona - mogą być naśladowani przez mówców, jak głosi Krassus:

Następnie ćwiczenia poruszeń głosu i oddechu, tak całego ciała, jak i samego języka, wymagają nie tyle teorii, ile wysiłku. W tych sprawach należy się dokładnie zastanowić, kogo chcemy naśladować i do kogo chcemy być podobni. Powinniśmy wziąć pod uwagę nie tylko mówców, lecz także aktorów, byśmy poprzez złe nawyki nie wpadli w jakieś szpetne skrzywienie. (Cyceron 2010: I 156)

Najbardziej frapujące porównanie mówcy z aktorem Roscjuszem i ostateczne rozstrzygnięcie, jaka jest relacja obu sztuk: oratorskiej i aktorskiej, daje Cyceron w wypowiedzi Antoniusza pod koniec księgi I. Bohater dialogu mówi:

Lecz tych rzeczy, które są dla mówcy niezbędne, jest tak wiele, są przy tym tak ważne i trudne, że nie chcę, by swój zapał trwonił on na inne zajęcia. Któż zaprzeczy, że mówca w swym ruchu i postawie podczas wygłaszania mowy powinien mieć gesty i wdzięk Roscjusza? Jednak nikt nie będzie przekonywał młodzieży pragnącej zgłębiać sztukę wymowy, by ucząc się gestykulacji trudzili się nad nią jak aktorzy. Czy coś jest mówcy równie niezbędne jak głos? A przecież zaręczam: nikt, kto pragnie zostać mówcą, nie będzie niewolnikiem głosu, jak greccy aktorzy tragiczni, którzy deklamują w pozycji siedzącej przez wiele lat i codziennie, zanim wystąpią publicznie, leżą i stopniowo pobudzają głos, po przedstawieniu zaś siedząc, schodzą z tonu najwyższego na najniższy i jakby go w ten sposób uspokajają. (Cyceron 2010: I 250-251)

Rozmówca widzi sprawę bardzo praktycznie, toteż pozwala sobie nawet zażartować z ceremonii poświęconych Apollinowi, podczas których aktorzy odśpiewywali w określonym porządku pieśni kultowe na cześć bóstwa:

Jeślibyśmy chcieli tak czynić, ci, których obrony się podjęliśmy, zostaliby skazani, zanim zdążylibyśmy odśpiewać pean lub nomos na cześć Apollina, tyle razy, ile się zaleca. (Cyceron 2010: I 252)

Następnie Antoniusz określa znaczenie gestu i głosu dla mówcy: gest „bardzo pomaga mówcy” (Cyceron 2010: I 252), a głos — „sam w najwyższym stopniu sztukę wymowy albo zaleca słuchaczom, albo wspiera” (Cyceron 2010: I 252), ale mówcy nie mogą sobie pozwolić na gorliwą pracę nad nimi i są w stanie „osiągnąć tyle tylko, na ile pozwala czas" (Cyceron 2010: I 252). Bohater dialogu czyni też interesujące rozróżnienie między kształceniem głosu i gestów, których „nie można natychmiast przejąć i wziąć skądkolwiek bądź" (Cyceron 2010: I 252), a kształceniem się w dziedzinie prawa - wiadomości prawnicze można bowiem uzyskać od specjalistów lub drogą lektury. Z porównania mówcy do Roscjusza Antoniusz wyprowadza również wniosek, że jak ów aktor odkrył, iż starzejąc się, może już zwolnić tempo recytacji 
i dostosować do nich akompaniament auletów, tak samo mówcom wolno z wiekiem mówić wolniej i łagodniej (Cyceron 2010: I 254-255).

Poprzez Antoniusza, nawiązując do życzenia Krassusa, aby każdy mówca był w swojej dziedzinie „jakby Roscjuszem” (Cyceron 2010: I 258), Cyceron dokonuje ostatecznego rozdzielenia komunikacji aktorów z widzami oraz komunikacji mówców ze słuchaczami:

Według mnie jednak na nasze błędy patrzy się z mniejszą odrazą niż na błędy aktorów. Tak też widzę, że często słucha się nas z najwyższą uwagą, nawet gdy jesteśmy zachrypnięci. Przyciąga bowiem sam temat i sprawa. (Cycero 2010: I 258-259)

Po tej obserwacji bohater przywołuje Klodiusza Ezopa, aktora współczesnego Roscjuszowi (z innych źródeł wiemy, że jego głosem Cyceron się zachwycał):

Ezopa zaś, gdy ma choćby niewielką chrypkę, wygwizduje się. W przypadku tych bowiem, od których nie oczekuje się niczego innego, jak tylko rozkoszy dla uszu, powoduje rozdrażnienie cokolwiek, co tylko zmniejsza rozkosz. W przypadku zaś wymowy jest wiele czynników, które potrafią przyciągnąć uwagę. I nawet jeśli wszystkie nie są na najwyższym poziomie, a jednak większość $\mathrm{z}$ nich jest wartościowa, to te właśnie, które takie są, niechybnie wydadzą się cudownymi. (Cyceron 2010: I 259)

\section{Następnie Antoniusz za wzór do naśladowania daje}

tego, którego wymowie przyznaje się niewątpliwie największą siłę wyrazu, mianowicie Ateńczyka Demostenesa, którego zapał, jak powiadają, i pracowitość były tak wielkie, że najpierw pokonał przeszkody naturalne dzięki pilności i pracowitości, chociaż miał tak złą dykcję, że nie potrafił wymówić nawet pierwszej litery tej sztuki, do której dążył, dzięki przygotowaniom osiągnął to, że uważano, iż nikt nie mówił od niego wyraźniej. (Cyceron 2010: I 260)

Okazuje się zatem, że wzorcem dla mówców może być trud zarówno aktora Roscjusza, jak i retora Demostenesa. Jeden osiąga doskonałość wygłoszenia dzięki pracy nad swoim talentem aktorskim; drugi osiąga ją dzięki transgresji, jaka powstała w wyniku połączenia talentu oratorskiego z niezłomną wolą pokonania wady wymowy.

Paralelny do tego fragment pojawi się później pod koniec księgi III traktatu O mówcy - odwołanie się do Demostenesa z najsilniejszym w całym traktacie wyeksponowaniem roli actio:

Samo wygłoszenie, powiem to dobitnie, ma w wymowie decydujące znaczenie. Bez niego nawet człowieka najbardziej wymownego nie można w ogóle zaliczyć do mówców, a biegły w tej sztuce mówca przeciętny często przewyższa najlepszych. Powiadają, że gdy zapytano Demostenesa, co jest najważniejsze w wymowie, wygłaszaniu właśnie przyznał i pierwsze, i drugie, i trzecie miejsce. (Cyceron 2010: III 213)

Sięgając do tych źródeł, poznajemy paradygmat kulturowy retoryki i pewną klasyczną tradycję poszukiwań oratorskiej doskonałości, a także jej zmienność dzieło Arystotelesa i dzieło Cycerona dzieli przecież długi okres, w którym relacje między różnymi dziedzinami sztuki ulegały przemianom. To jednak nie wszystko — odkrywamy również w antycznej teorii retoryki określone idee aksjologiczne i wyznaczone przez nie postawy twórcze. 
Chyba najsilniej uobecnia się tutaj para idei, którą Władysław Stróżewski uważa za jedną z najważniejszych: nowatorstwo i perfekcjonizm (Stróżewski 2007: 415). Nie zachodzi pomiędzy nimi prosta opozycja - tak jak nie zachodzi między sztuką retorów a sztuką aktorów. Nowatorstwo wiąże się z pojęciem nowości, perfekcjonizm - z pojęciem doskonałości. Co ciekawe, różnice między tymi dwoma jakościami nie powodują ich konfliktu, choć „nowość otwiera, ale i rozprasza”, natomiast „doskonałość koncentruje, skupia” (Stróżewski 2007: 424). Mówca przed każdym zdarzeniem retorycznym i w samym zdarzeniu jest obarczony tym, że słuchacze oczekują od niego doskonałości, oczekują takiej realizacji wszystkich pięciu powinności, która utworzy doskonałą całość — gdyż „doskonałe jest to, co proste, jednolite, niezłożone”, oraz „doskonałe jest to, co harmonijne, zbudowane wedle jednej zasady”, jak też „doskonała jest zgodność w różnorodności”, wedle słów Władysława Tatarkiewicza (Tatarkiewicz 1976: 10-11). Postawa perfekcjonizmu skłania zatem retora do kształcenia tych umiejętności z zakresu actio, które należą do zestawu umiejętności aktora. Jednakże zarówno Arystoteles, jak i Cyceron uświadamiali sobie rolę innego wektora w twórczości oratorskiej - potrzebę nowatorstwa, regulującą owo dążenie do doskonałości. Nowatorstwo zaś to nie tylko zdobywanie nowości, lecz także poszukiwanie zupełnie nowych możliwości, które nie są miażdżone bezbłędnym, mistrzowskim opanowaniem rzemiosła - w tym wypadku aktorskiego. Stróżewski wyodrębnia zatem w sztukach dwie odmiany doskonałości: zamkniętą i otwartą (Stróżewski 2007: 420-426). Wydaje się, że żywioł retoryczny może trwać wyłącznie w tej drugiej. Autor Dialektyki twórczości podpowiada:

Istnieją realizacje doskonałe, ale i tak bogate zarazem, że nie sposób w jednym dziele, w jednym życiu, w jednym kierunku wyczerpać wszystkich konsekwencji, jakie się w nich zawierają. Stąd możliwość kontynuacji, tzn. różnorodnego wypełniania zmiennych zawartości rządzących nimi idei (odwołuję się znów do Ingardenowskiej teorii idei), mimo że inne spośród tych zmiennych znalazły w dziełach-wzorcach doskonałe urzeczywistnienie. (Stróżewski 2007: 422)

Ten model doskonałości idealnie odpowiada celom sztuki retorycznej. Ona cała wyraża się w kontynuacji, w cyklicznych wystąpieniach najwybitniejszych mówców, w ponawianiu kontaktu ze słuchaczami. Zgodnie z tym modelem może również pracować nad swoim warsztatem aktor, lecz w innym celu, gdyż doskonałość jego dzieła jest inna.

\section{Bibliografia}

\section{Źródła}

Arystoteles (2014): Retoryka. Retoryka dla Aleksandra. Poetyka, przekład, wstęp i komentarz H. Podbielski, Warszawa.

Marek Tulliusz Cyceron (2010): O mówcy, przekład, wstęp i komentarz B. Awianowicz, Seria dwujęzyczna „Ad Fontes” XIX, Kęty. 
Marek Fabiusz Kwintylian (2002): Kształcenie mówcy. Księgi I, II, X, przekład i oprac. M. Brożek, Warszawa.

The Rhetoric of Aristotle (1877): edited by J.E. Sandys with a commentary by E.M. Cope, vol. 3, Cambridge.

\section{Opracowania}

Awianowicz B. (2010): Wprowadzenie, [w:] Marek Tulliusz Cyceron, O mówcy, przekład, wstęp i komentarz B. Awianowicz, Kęty, s. 5-41.

Douglass R.B. (2008): Arystotelesowska koncepcja komunikacji retorycznej, przeł. W. Krajka, [w:] Retoryka, red. M. Skwara, Gdańsk.

Koracic A. (2021): Aristotle on Language and Style. The Concept of Lexis, Cambridge.

Korolko M. (1990): Sztuka retoryki. Przewodnik encyklopedyczny, Warszawa.

Kotlarczyk M. (1965): Podstawy sztuki żywego słowa. (Instrument - dykcja - ekspresja), Warszawa.

Merleau-Ponty M. (1999): Proza świata. Eseje o mowie, przeł. E. Bieńkowska, S. Cichowicz, J. Skoczylas, Warszawa.

Podbielski H. (2014): Wstęp tłumacza, [w:] Arystoteles, Retoryka. Retoryka dla Aleksandra, przekład, wstęp i komentarz H. Podbielski, Warszawa, s. 8-43.

Radziwiłowicz J. (2011): Wymyślanie cudzego tekstu, czyli retoryka w wydaniu posiadaczy praw autorskich pokrewnych, [w:] Dydaktyka retoryki, red. B. Sobczak, H. Zgółkowa, Poznań, s. 156-159.

Rzymowska L. (2013): U źródeł pojmowania retoryki, Wrocław.

Słownik grecko-polski (1965): red. Z. Abramowiczówna, t. 4, Warszawa.

Sobczak B. (2009): Retoryka a niejęzykowe środki komunikacji, „Poznańskie Studia Polonistyczne. Seria Językoznawcza", t. 15 (35), s. 57-76.

Stróżewski W. (2007): Dialektyka twórczości, Kraków.

Swieżawski S. (2000): Dzieje europejskiej filozofii klasycznej, Warszawa-Wrocław.

Tatarkiewicz W. (1976): O doskonałości, Warszawa.

Ziomek J. (2000): Retoryka opisowa, Warszawa-Wrocław.

\section{The artistry of the orator and the artistry of the actor in the Graeco-Roman rhetorical tradition}

\section{Summary}

In a short sketch, the author presents broadly the problems of the fifth part of the art of rhetoric, that is, pronunciation (actio), as an area in which the similarities and differences between rhetoric and acting are revealed - a topic which is worthy of a separate monograph. The first part of the text is devoted to a brief ordering of these issues, while the second part constitutes an analysis and interpretation of fragments of two ancient sources that can be used to describe the separation of the art of oratory and the art of acting in the history of Graeco-Roman rhetoric. These are: Book III of Aristotle's Rhetoric and Book I of the treatise On the orator by Marcus Tullius Cicero.

Keywords: language, communication, art of rhetoric, art of acting, Aristotle, Cicero, orator, actor, actio, pronunciation, recitation, voice, gestures, body movement, Rhetoric, On the orator. 